\title{
Economic analysis of traditional coconut oil production in Aceh Besar, Indonesia
}

\author{
${\text { Rahmattullah*1, }{ }^{1} \text { Muhammad }}^{2}$, Muhammad Nasir Ismail $^{3}$ \\ ${ }^{12}$ STKIP BBG Banda Aceh, Indonesia \\ ${ }^{3}$ Abulyatama University, Indonesia
}

\begin{abstract}
The purpose of this study was to analyse the rentability and profit of traditional coconut oil production.Primary data was obtained by using survey method. Data collection techniques are conducted by census. The processing of oil is done by 6 respondents fermentation and 6 respondents cooking coconut milk. Theresults show that coconut oil production cooking coconut milk is more advantageous in terms of rentabilityand profit. The recommendation given is that the rural mothers switch from fermentation to cooking ofcoconut milk.
\end{abstract}

Keywords : economic analysis, production, traditional coconut oil, fermentation, cooking of coconut milk

\section{Introduction}

Efforts to improve the quantity and quality of coconut oil with traditional systems required profit calculations. Proper coconut oil processing, cost, and pricing can increase the benefits of rural mothers. Traditional oil processing through the cooking of coconut milk takes 2 days, through 4 stages of production process, not affected by weather condition while fermentation process takes 2 weeks, through 6 stages of production process, influenced by weather condition

Although rural mothers in Aceh Besar to produce coconut oil have carried out the process, they have not yet found a problem solving the profit analysisis. Technical treatment, and quality of raw materials affect against coconut oil.

Starting from the above problems should the rural mothers have to take into account the cost of production without ignoring the quality of the coconut oil. So it can compete with palm oil factory production. Therefore, to know which is more advantageous between fermentation system with cooking system of coconut milk from rentability and profit needed a research.

\section{Research of Previous and hypothesis}

\subsection{Previous research}

Cost-profit has been studied by Manajit N (2011). Costs and Economies of Scale ever studied by Mourão P et al (2017). The optimality of full-cost pricing was studied by Coller $C$ et al (2015). Capital maintenance and depreciation has been studied by Albonico. A et al (2014). Profit maximization has been studied by Levin EJ et al (2004), Dierker E and Grodal B (1996). Joint decision making for production and marketing was investigated by Ulusoy G and Yazgac T (1995). Cost-Benefit Analysis was studied by Khoshgoftaar $\mathrm{TM}$ et al (2001). Balancing expected profit and conditional value-at-risk have been studied by Xu M et al (2010). Profit sharing increase has been studied by Kim S (1998). Profit functions have been studied by Khumbhakar SC (2006). Maximizes the rate of profit ever studied by Nekipelov AD (2013). Theory of Profit has been studied by Battistini A (2013). Measuring productive efficiency has been studied by Mulwa R (2013). Asymmetric holding cost information was investigated by Voigt G \& Guericke OV (2015). Profit maximization was studied by Anderson WL \& Ross RL (2005). Pricing Strategies have been studied by Sibly H (2017). A capacitated firm's pricing strategies have been investigated by Wang, M et al (2016). Profit maximization has been studied by Dierker E and Grodal B (1996). The impacts of product market 
competition have been studied by Li X (2010). Economic profitability has been studied by Yuan et al (2017).

\subsection{Hypothesis}

Hypothesis of this research are:

It is estimated that the traditional processing coconut oil of cooking system of coconut milk is more advantageous than fermentation system.

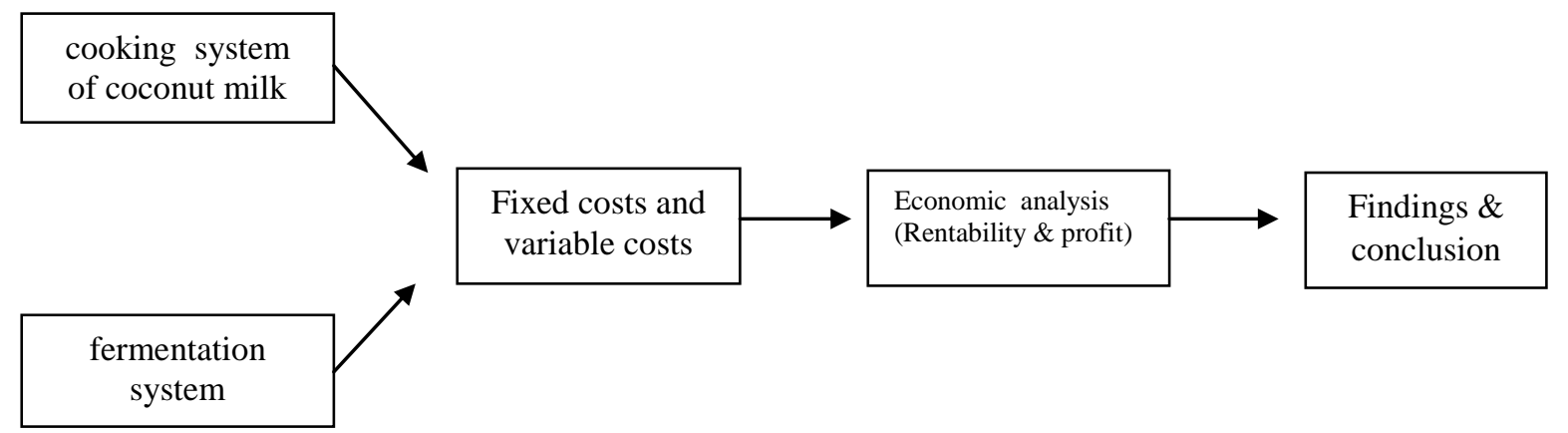

\section{Methods and Model}

\subsection{Methods}

\section{a. Location, Object and Scope of Research}

This research was conducted in Aceh Besar District. The determination of Aceh Besar District as the location of the research is purposive (Purposive Sampling) based on the consideration that there are rural ladies of fermented coconut oil processing and cooking of coconut milk

The object of this research was rural mothers who processed coconut oil traditional by fermentation and cooking of coconut milk. The scope of this study is limited to the analysis of profit of processing coconut oil with traditional systems.

\section{b.Sampling Technique}

The population of this study were rural mothers who processed fermented oil and cooking of coconut milk. The method of determining sample farmers from the population of each village is done by using the complete counting method, because the number of respondents is only 12 people, 6 people are fermented and 6 respondents are cooking coconut milk.

\subsection{Model}

To test the hypothesis used 2 benchmarks, namely:

\section{a.Rentability}

Rentability calculation used general formula as follows:

$\mathrm{R}=\mathrm{L} / \mathrm{M} \times 100 \%$

Where:

$\mathrm{R}=$ Rentability

$\mathrm{L}=$ Profit

$\mathrm{M}=$ Capital or Production Cost

To calculate the profitability of each processing process is translated into the following formula:

$\mathrm{X}_{1} / \mathrm{M}_{1} \times 100 \%=\mathrm{Y}_{1}$

$\mathrm{X}_{2} / \mathrm{M}_{2} \times 100 \%=\mathrm{Y}_{2}$

Where :

$\mathrm{X}_{1}=$ fermentation advantage

$\mathrm{X}_{2}=$ Benefits of cooking of coconut milk

$\mathrm{M}_{1}=$ Cost of fermentation production

$\mathrm{M}_{2}=$ Production cost of cooking of coconut milk

$\mathrm{Y}_{1}=$ fermentation profitability

$\mathrm{Y}_{2}=$ Rentability of cooking of coconut milk

With the following conditions:

If $Y_{1}>Y_{2}$ means $Y_{1}$ is more advantageous than $Y_{2}$ 
If $Y_{2}>Y_{1}$ means $Y_{2}$ is more advantageous than $Y_{1}$

\section{b.Profit}

$\mathrm{K}_{\mathrm{f}} / \mathrm{H}=\mathrm{K}_{1}$

The calculation of profit per day of fermentation is used as follows :

Where:

$\mathrm{K}_{\mathrm{f}}=$ Advantages of fermentation

$\mathrm{H}=$ Day

$\mathrm{K}_{1}=$ The profit per day of fermentation

The calculation of profit per day of cooking of coconut milk is used as follows:

$\mathrm{K}_{\mathrm{p}} / \mathrm{H}=\mathrm{K}_{2}$

Where:

$\mathrm{K}_{\mathrm{p}}=$ The advantage of cooking of coconut milk

$\mathrm{H}=$ Day

$\mathrm{K}_{2}=$ The profit per day of cooking of coconut milk

With the following conditions :

If $\mathrm{K}_{1}>\mathrm{K}_{2}$ means $\mathrm{K}_{1}$ is more advantageous than $\mathrm{K}_{2}$

If $\mathrm{K}_{2}>\mathrm{K}_{1}$ means $\mathrm{K}_{2}$ is more advantageous than $\mathrm{K}_{1}$

\section{c.Assumptions:}

- Type of coconut used is traditional coconut

- The price of coconut per fruit during the study is Rp.1500, -

- The price of fermented oil is $23,400,-/ \mathrm{kg}$

- The price of cooking oil of coconut milk is $26,600,-/ \mathrm{kg}$

- By-products are not taken into account

\section{Result and Discussion}

The research results obtained an average of 100 pieces of coconut that is produced by the process of fermentation oil processing of $9.6 \mathrm{~kg}$ and cooking of coconut milk of $10.42 \mathrm{~kg}$. The average profit of fermented respondents is Rp.22.075.60 and cooking of coconut milk is Rp.33.465,90

The first benchmark testing of the processing profits above is based on profitability. The profitability of fermentation processing is $11 \%$. This means every cost incurred Rp.1000.00 will increase profit Rp.111.00. Result of calculation rentability of coconut milk obtained Rp.140,00. This means that any cost incurred Rp.1000.00 will add profit Rp.140.00.

In this study, the fermentation rentability is denoted by $\mathrm{Y}_{1}$ and the rentability of coconut milk with $\mathrm{Y}_{2}$. The profitability benchmark states that if $Y_{1}>Y_{2}$ means $Y_{1}$ is more appealing than $Y_{2}$ and if $Y_{2}>Y_{1}$ means $Y_{2}$ is more advantageous than $Y_{1}$, Since $Y_{2}>Y 1$ then a benchmark representing $Y_{2}$ is more advantageous than $Y_{1}$ received. The second benchmark of profit processing testing is based on the profit per day. Based on the above research obtained profit per day of fermentation of Rp.1.471.70. This means that from 15 days of processing with fermentation got profit per day equal to Rp.1.471,70 although total profit obtained during one processing process equal to Rp.22.075,70,

The profit per day from cooking of coconut milk is Rp.16.733,0 although the total profit obtained during the processing once is Rp.33.465,9. In this study, the profit per day of fermentation is denoted by $\mathrm{K}_{1}$ and the profit per day of cooking of coconut milk is denoted by $\mathrm{K}_{2}$. The benchmark per day profit indicates that if $\mathrm{K}_{1}>\mathrm{K}_{2}$ means $\mathrm{K}_{1}$ is more advantageous than $\mathrm{K}_{1}$. Because $\mathrm{K}_{2}>\mathrm{K}_{1}$ then benchmark profit per day stating that $\mathrm{K}_{2}$ is more profitable than $\mathrm{K}_{1}$ accepted.

From the above description shows that the processing process with the cooking of coconut milk is more advantageous than the fermentation both in the test of profitability and profit per day.

\section{Conclusion}

In an effort to increase the profits of rural mothers for the future, it is recommended that they switch the traditional processing coconut oil of system fermentation to cooking coconut milk system.

\section{References}


1. Albonico, A. et. al. (2014), Capital maintenance and depreciation over the business cycle. Journal of Economic Dynamics and Control, 39, 273-286.

2. Anderson, W.L. \& Ross, R.L. (2005), The methodology of profit maximization: An Austrian alternative, The Quarterly Journal of Austrian Economics, Volume 8, Issue 4, pp 31-44.

3. Battistini, A. (2013), A Theory of Profit and Competition, Evolutionary and Institutional Economics Review, Volume 10, Issue 2, pp 269-294.

4. Coller, C. et. al. (2015), The optimality of full-cost pricing: a simulation analysis of the priceadjustment dynamics, Journal of Management Control, Volume 26, Issue 2-3, pp 157-191.

5. Dierker, E. and Grodal, B. (1996), Profit maximization mitigates competition, Economic Theory, Volume 7, Issue 1, pp 139-160.

6. Khoshgoftaar, T.M. et. al. (2001), Cost-Benefit Analysis of Software Quality Models, Quality Journal, Volume 9, Issue 1, pp 9-30.

7. Khumbhakar, S.C. (2006), Specification and estimation of nonstandard profit functions, Empirical Economics, Volume 31, Issue 1, pp 243-260.

8. Kim, S. (1998), Does profit sharing increase firms' profits?, Journal of Labor Research, Volume 19, Issue 2, pp 351-370.

9. Levin, E.J. et. al. (2004), Profit maximization in a multi-product firm with impatient customers, Journal of the Operational Research Society, Volume 55, Issue 3, pp 211-218.

10. Li, X. (2010), The impacts of product market competition on the quantity and quality of voluntary disclosures, Review of Accounting Studies, Volume 15, Issue 3, pp 663-711.

11. Manajit, N. (2011), Cost-profit analysis of Japanese-type set-net through technology transfer in Rayong, Thailand, Fisheries Science, Volume 77, Issue 4, pp 447-454.

12. Mourão, P. et. al. (2017), Costs and Economies of Scale at Not-for-Profit Organizations: The Case of the Santa Casa da Misericórdia de Barcelos Between 2002 and 2013, Volume 132, Issue 2, pp 821-840.

13. Mulwa, R. (2013), Measuring productive efficiency using Nerlovian profit efficiency indicator and metafrontier analysis, Operational Research, Volume 13, Issue 2, pp 271-287.

14. Nekipelov, A.D. (2013), Behavior of a firm which maximizes the rate of profit: Specific features, Studies on Russian Economic Development, Volume 24, Issue 3, pp 208-219.

15. Sibly, H. (2017), Pricing Strategies with Costly Customer Arbitrage, Review of Industrial Organization, Volume 50, Issue 3, pp 345-366.

16. Ulusoy, G. and Yazgac, T. (1995), Joint decision making for production and marketing. Int J Prod Res 33: 2277-2293.

17. Voigt, G. \& Guericke, O.V. (2015), Inequity aversion in a joint economic lot sizing environment with asymmetric holding cost information, Journal of the Operational Research Society, Volume 66, Issue 4, pp 554-569.

18. Wang, M. et. al. (2016), A capacitated firm's pricing strategies for strategic consumers with different search costs, Annals of Operations Research,Volume 240, Issue 2, pp 731-760.

19. Xu, M. et. al. (2010), Optimal decisions when balancing expected profit and conditional value-atrisk in newsvendor models, Journal of Systems Science and Complexity, Volume 23, Issue 6, pp 1054-1070. 